\title{
Acid Production from Mixed Sulfide Minerals: The Mixture Pyrite/Arsenopyrite
}

\author{
C.M.V.B. Almeida, B.F. Giannetti * \\ Universidade Paulista, Instituto de Ciências Exatas e Tecnologia, 04026 002, São Paulo, Brasil
}

Received 10 September 2002; accepted 23 July 2003

\begin{abstract}
To evaluate the response of pyrite and arsenopyrite to oxidizing conditions, an electrochemical approach was employed, to set boundaries for the influence of the arsenopyrite content. The effects of galvanic interactions and local $\mathrm{pH}$ on the oxidation reaction of pyrite were also studied. With this purpose, artificial two-mineral electrodes were constructed ranging in concentration from $20-80 \%$ arsenopyrite. The resulting cyclic voltammograms were analyzed and relative quantities of oxidation products were evaluated.
\end{abstract}

Keywords: sulfide mixtures, pyrite, arsenopyrite, oxidation.

\section{Introduction}

The mining and mineral processing of sulfide ores can generate large quantities of tailings and waste rock that contain pyrite and arsenopyrite. When these sulfides are exposed to air and water, they readily undergo aqueous and atmospheric oxidation and cause acid generation. These processes contribute to the formation of acid mine drainage.

The acid mines drainage accounts for the pollution of water, air, land, and causes risky damages to the environment. Thus, the characterization of complex mineral assemblages containing $\mathrm{S}$ compounds is important to waste characterization. In spite of the importance of mineral weathering behaviour, little is known about the acid generation characteristics of common sulfide minerals. The aim of this work

\footnotetext{
* Corresponding author. E-mail address: biafgian@unip.br
} 
is to define the limit conditions, in terms of arsenopyrite content in the mixture, that determine the $\mathrm{SO}_{4}{ }^{2-} / \mathrm{S}$ ratio obtained and to describe some parameters which influence this ratio and the release of As to the environment. Remediation strategies for polluted land containing reduced $\mathrm{S}$ minerals must first consider the composition of waste rock that contains pyrite and arsenopyrite.

\section{Experimental}

The ore pyrite and arsenopyrite samples investigated are from Morro Velho Mine, in Nova Lima, Minas Gerais, Brazil. The minerals were hand ground in an agate mortar and pestle. This material was then sieved to isolate the fraction containing particles $<210 \mu \mathrm{m}$, in size.

Potentiodynamic measurements were carried out in a standard electrochemical cell. The carbon paste electrodes consisted of $1.0 \mathrm{~g}$ graphite and $1.2 \mathrm{~g}$ paraffin containing $5 \mathrm{mg}$ of ground mineral. The reference electrode was an $\mathrm{Ag} / \mathrm{AgCl}$ electrode placed in a Luggin-Haber capillary and the counter electrode was a platinized platinum wire of large area. The electrolyte buffer, acetic acid/sodium acetate, $\mathrm{pH}=4.5$ was prepared from Merck p.a. grade reagent and triply distilled water. Nitrogen was bubbled through the cell to deaerate the solution. Potential values quoted in this text are given on the standard hydrogen scale. All experiments were carried out at $25{ }^{\circ} \mathrm{C}$ and scan rate of $20 \mathrm{mV} \mathrm{s}^{-1}$.

\section{Results and Discussion}

As carbon paste electrodes containing ground mineral were employed, voltammograms of arsenopyrite alone were performed in order to compare the data obtained with those found in the literature. A short discussion is presented herein to give support to the results concerning the mixed-mineral electrodes. The electrochemical behaviour of pyrite is fairly discussed in literature $[1,2]$.

The voltammogram of arsenopyrite, in acetic acid/sodium acetate buffer, $\mathrm{pH}=$ 4.5, is shown in Fig. 1. When the scan is initiated at the open circuit potential $\left(\mathrm{E}_{\mathrm{oc}}\right)$ in the positive direction, two anodic current peaks, $\mathrm{A}_{2}$ and $\mathrm{A}_{1}$, are observed. 
The appearance of current peak $\mathrm{A}_{2}$ at $0.35 \mathrm{~V}$ is consistent with the formation of $\mathrm{Fe}(\mathrm{OH})_{3}[1]$.

The region of potentials of current peak $A_{1}$ is associated in literature $[3,4]$ with a two-step mechanism. However, there is no agreement on which are the two steps. Sanchez and Hiskey [5] argue that the first step results in the formation of an iron hydroxide/oxide, $\mathrm{SO}_{4}{ }^{2-}$ and $\mathrm{H}_{2} \mathrm{AsO}_{3}{ }^{-}$. The second step involves the oxidation of $\mathrm{H}_{2} \mathrm{AsO}_{3}{ }^{-}$to $\mathrm{HAsO}_{4}{ }^{-}$. To Lin and Zheng [3], the initial step is the oxidation of sulfide to sulfur and $\mathrm{H}_{2} \mathrm{AsO}_{3}{ }^{-}$. The second step is the oxidation of sulfur to sulfate and arsenate. Reactions (1) and (2) are thermodynamically possible. The authors $[3,5]$ do not consider the formation of insoluble species of arsenic compounds.

$$
\begin{aligned}
& \mathrm{FeAsS}+11 \mathrm{H}_{2} \mathrm{O} \rightarrow \mathrm{Fe}(\mathrm{OH})_{3}+\mathrm{H}_{2} \mathrm{AsO}_{4}^{-}+\mathrm{SO}_{4}{ }^{2-}+17 \mathrm{H}^{+}+14 \mathrm{e}^{-} \\
& \mathrm{Fe}^{2+}+3 \mathrm{H}_{2} \mathrm{O} \rightarrow \mathrm{Fe}(\mathrm{OH})_{3}+3 \mathrm{H}^{+}+\mathrm{e}^{-}
\end{aligned}
$$

At more positive potentials, $\mathrm{E}>0.85 \mathrm{~V}$, the current for the reverse scan is greater than that for the forward sweep, Fig. 1B. In fact, when successive cycling is carried out with a crystal electrode, the cathodic and anodic charges increase gradually. When the cycling is carried out with the ground mineral electrode, after an increase of charge, the currents decrease, indicating the dissolution of the particles. Thus, the hysteresis observed is indicative of an increase in the surface area of the electrode because of oxidation.
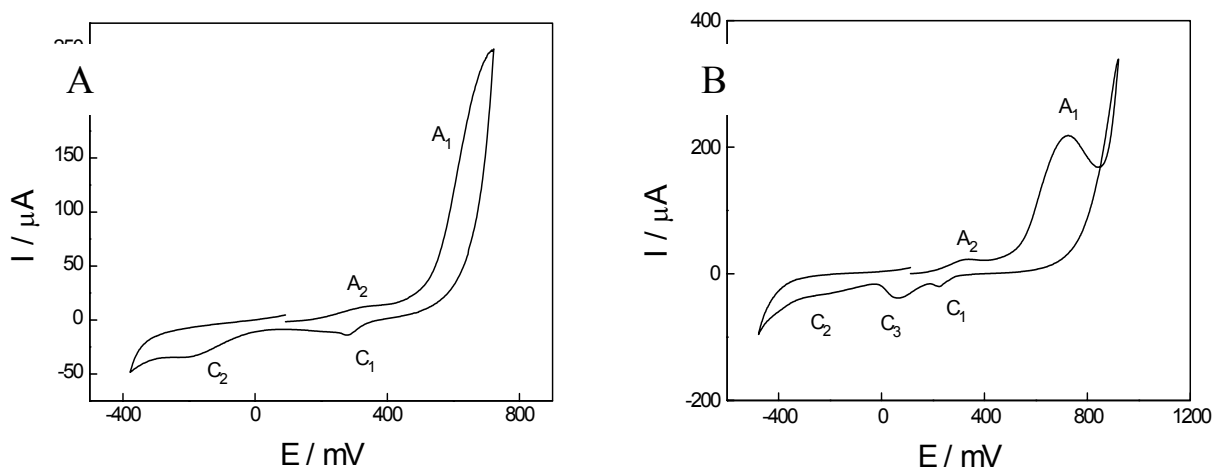

Figure 1. Cyclic voltammogram of arsenopyrite, $\mathrm{pH}=4.5$ and $\mathrm{v}=20 \mathrm{mV} \mathrm{s}^{-1}$. (A) $\mathrm{E}_{\mathrm{i}}=\mathrm{E}_{\mathrm{f}}$ $=\mathrm{E}_{\mathrm{oc}}, \mathrm{E}_{\lambda \mathrm{a}}=0.922 \mathrm{~V}, \mathrm{E}_{\lambda \mathrm{c}}=-0.6 \mathrm{~V}$ and $(\mathrm{B}) \mathrm{E}_{\mathrm{i}}=\mathrm{E}_{\mathrm{f}}=\mathrm{E}_{\mathrm{oc}}, \mathrm{E} \lambda \mathrm{a}=0.90 \mathrm{~V}, \mathrm{E} \lambda \mathrm{c}=-0.4 \mathrm{~V}$. 
In the reverse scan, three current peaks are observed. Current peak $C_{1}$ is associated with the reduction process of $\mathrm{Fe}(\mathrm{OH})_{3} / \mathrm{Fe}^{2+}$ formed in current peak $\mathrm{A}_{2}$. Current peak $\mathrm{C}_{2}$ may be related to the reduction of sulfur formed during oxidation.

The analysis of the oxidation products of arsenopyrite in acidic media, at $25{ }^{\circ} \mathrm{C}$, results in the presence of $\mathrm{As}(\mathrm{III})$ and $\mathrm{As}(\mathrm{V})$ in solution $[6,7]$. The E-pH diagram of arsenopyrite $[8,9]$ indicates the reducing reactions, in the potential range of current peak $\mathrm{C}_{3}$, could be:

$$
\begin{aligned}
& \mathrm{H}_{2} \mathrm{AsO}_{4}^{-}+2 \mathrm{H}^{+}+2 \mathrm{e}^{-} \rightarrow \mathrm{H}_{2} \mathrm{AsO}_{3}^{-}+\mathrm{H}_{2} \mathrm{O} \\
& \mathrm{As}_{2} \mathrm{~S}_{3}+2 \mathrm{H}^{+}+2 \mathrm{e}^{-} \rightarrow \mathrm{As}_{2} \mathrm{~S}_{2}+\mathrm{H}_{2} \mathrm{~S}
\end{aligned}
$$

Thus, current peak $\mathrm{C}_{3}$ may be attributed to the reduction of arsenic compounds. Orpiment, $\mathrm{As}_{2} \mathrm{~S}_{3}$, is an insoluble yellow solid in acidic media [10] and stirring the solution may not interfere with its rate of reduction, while $\mathrm{H}_{2} \mathrm{AsO}_{4}^{-}$would disperse in solution. As current peak $\mathrm{C}_{3}$ doesn't change under stirring, the reduced species in this potential range must be on the electrode surface.

The two-mineral electrodes were made with pyrite, which has the most known electrochemical behaviour and arsenopyrite ranging 20-100 \% by weight. Fig. 2 shows the effect of the FeAsS presence on the pyrite voltammogram. Increasing the arsenopyrite content increases the value of the current a1, i.e., the electrode surface becomes more active. This is probably due to the formation of soluble arsenic compounds.

When the arsenopyrite content is greater than $40 \%$, the current peak $\mathrm{C}_{3}$ appears. This peak was previously observed in the voltammogram of arsenopyrite alone and was associated to the reduction of $\mathrm{As}_{2} \mathrm{~S}_{3}$ produced during the positive scan. The current peak $\mathrm{C}_{2}$ does not present a significant increase, indicating that the pyrite/arsenopyrite combination favours the soluble compounds production. 


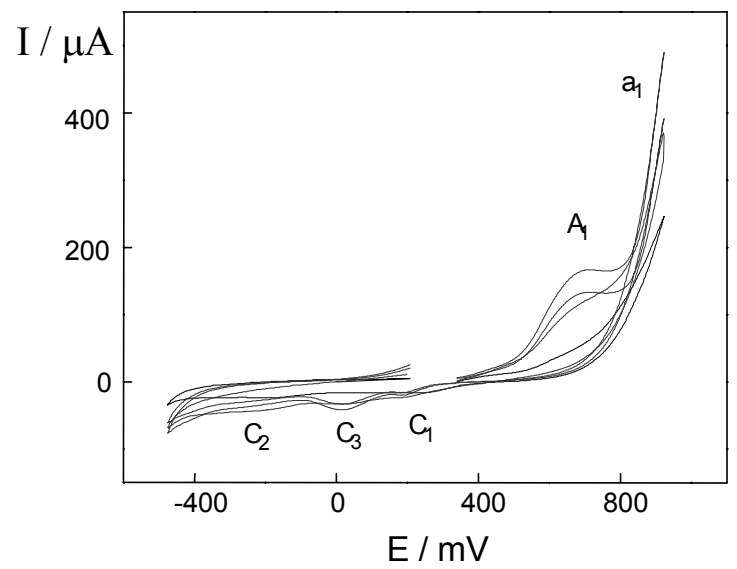

Figure 2. Cyclic voltammograms of the two-mineral electrodes.

The charges associated with the surface processes were evaluated indirectly employing reduction charge values and the stoichiometry of the reactions involved. It was assumed that the reduction of $\mathrm{Fe}(\mathrm{OH})_{3}$ and $\mathrm{As}_{2} \mathrm{~S}_{3}$ are complete in the potentials $0.17 \mathrm{~V}$ and $-0.05 \mathrm{~V}$, respectively. Iron oxides with different degrees of hydration from $\mathrm{Fe}(\mathrm{OH})_{3}$ were not considered. The cathodic charge associated with the mineral decomposition was subtracted from the total cathodic charge. To evaluate the quantities of $\mathrm{SO}_{4}{ }^{2-}, \mathrm{S}, \mathrm{Fe}(\mathrm{OH})_{3}$ and soluble arsenic compounds produced by the electrodes, relative quantities of soluble compounds, ferric hydroxide, and elemental sulfur were calculated as shown in table 1.

Table 1. Evaluation of the relative quantities of oxidation products generated by the two-mineral electrodes.

\begin{tabular}{llll}
\hline \multicolumn{1}{c}{$\%$} & & \multicolumn{1}{c}{$\times 100$} & \multicolumn{1}{c}{$\mathrm{E} / \mathrm{V}$} \\
\hline $\mathrm{Fe}(\mathrm{OH})_{3}$ & $=$ & $\left(\mathrm{Q}_{\mathrm{c} 1} / \mathrm{Q}_{\mathrm{a}}\right)$ & $\mathrm{E}_{\mathrm{ca}} \leq \mathrm{E} \leq 1.0 \mathrm{~V}$ \\
$\mathrm{~S}$ & $=$ & $\left(\mathrm{Q}_{\mathrm{c} 2} / \mathrm{Q}_{\mathrm{a}}\right)$ & $\mathrm{Eca} \leq \mathrm{E} \leq 1.0 \mathrm{~V}$ \\
$\mathrm{As}_{2} \mathrm{~S}_{3}$ & $=$ & $\mathrm{E}>0.85 \mathrm{~V}$ \\
$\mathrm{SO}_{4}{ }^{2-}$ & $\left.\left(\mathrm{Q}_{\mathrm{a}}-\mathrm{Q}_{\mathrm{c}}\right) / \mathrm{Q}_{\mathrm{a}}\right]$ & $\mathrm{E} \leq 0.85 \mathrm{~V}$ \\
$\left(\mathrm{SO}_{4}^{2-}+\mathrm{As}_{(\mathrm{aq})}\right)$ & $=$ & $\mathrm{E}>0.85 \mathrm{~V}$ \\
\hline
\end{tabular}

Fig. 3 shows the variation of the Qa/Qc ratio with the anodic end-point potential, $\mathrm{E} \lambda \mathrm{a}$, (a) for pyrite and arsenopyrite electrodes and (b) for the two-mineral electrodes. For potentials more negative than $1.0 \mathrm{~V}$, the two-mineral electrodes are less active than the pyrite electrodes and, despite of the surface composition, 
produce similar quantities of soluble products. However, at potentials more positive than $1.0 \mathrm{~V}$, the presence of arsenopyrite increases the oxidation rate of the two-mineral electrodes. There is no linear relationship between the activity of the electrodes and the percentage of arsenopyrite.
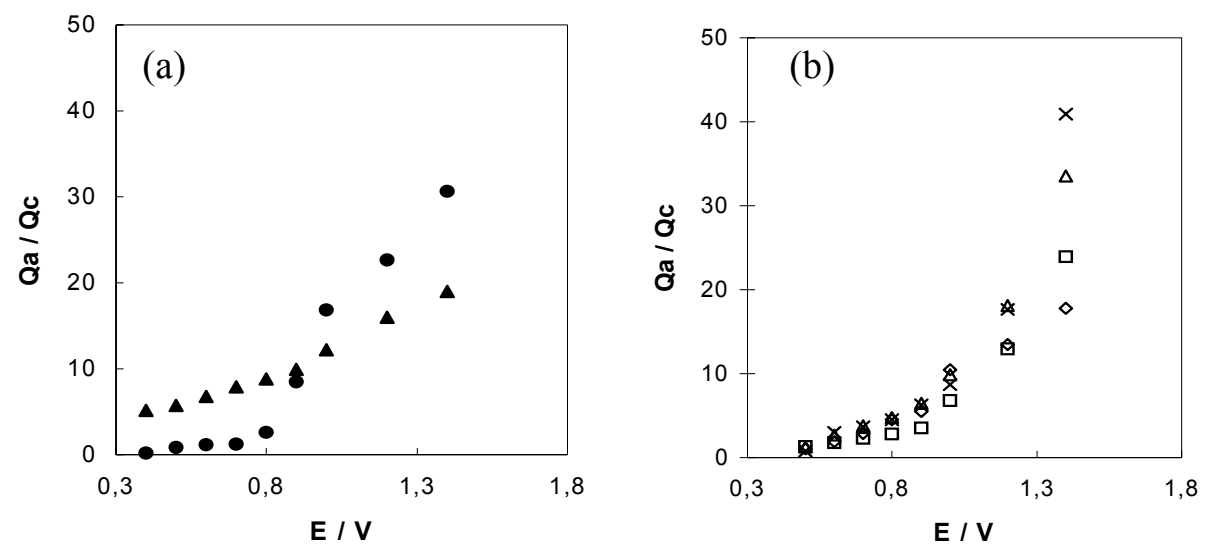

Figure 3. Dependence of the ratio $\mathrm{Q}_{\mathrm{a}} / \mathrm{Q}_{\mathrm{c}}$ on the anodic potential limit: $(\boldsymbol{\Delta})$ pyrite alone, $(\bullet)$ arsenopyrite alone and pyrite plus: $(\diamond) 20 \%$ arsenopyrite, $(\square) 40 \%$ arsenopyrite, $(\Delta)$ $60 \%$ arsenopyrite and (x) $80 \%$ arsenopyrite.

Fig. 4 shows the variation of $\% \mathrm{SO}_{4}{ }^{2-}$ obtained from the electrodes as a function of the anodic end point potential. The $\mathrm{SO}_{4}{ }^{2-}$ yield increases with potential to all electrodes. However, when mixed-mineral electrodes are used, two different potential regions are noticed. At potentials more negative than $1.0 \mathrm{~V}$ the presence of arsenopyrite seems to inhibit the sulfate production. The relative quantity of sulfate produced by all electrodes reaches a maximum value to $E_{\lambda \mathrm{a}} \geq 1.0 \mathrm{~V}$ and the oxidation becomes independent on the composition of the electrode.

Opposite behaviour is noticed when the relative quantities of sulfur are evaluated (Fig. 5). Two different potential regions are also noticed. The $\% \mathrm{~S}$ decreases as a function of $\mathrm{E}_{\lambda \mathrm{a}}$ and reaches a minimum value at potentials more positive than $1.0 \mathrm{~V}$. At potentials more negative than $1.0 \mathrm{~V}$ sulfur production increases. It is worth noting that the production of elemental sulfur by arsenopyrite alone is limited to $50 \%$ as it is in pyrite alone [11], which suggests that the arsenopyrite 
oxidation mechanism may be similar to that of pyrite. However, the mixed minerals present different behaviour.
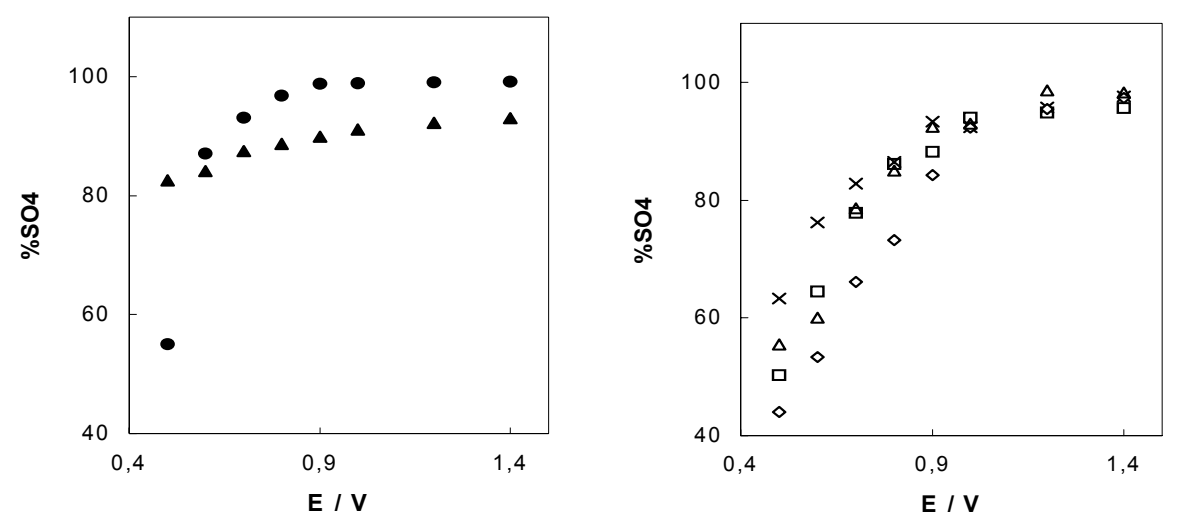

Figure 4. Dependence of $\% \mathrm{SO}_{4}{ }^{2-}$ on the anodic potential limit: $(\boldsymbol{\Delta})$ pyrite alone, $(\bullet)$ arsenopyrite alone and pyrite plus: $(\diamond) 20 \%$ arsenopyrite, $(\square) 40 \%$ arsenopyrite, $(\Delta)$ $60 \%$ arsenopyrite and $(\times) 80 \%$ arsenopyrite.

The pyrite and arsenopyrite electrodes show a decrease of the $\% \mathrm{Fe}(\mathrm{OH})_{3}$ with increasing the potential (Fig. 6). The production of iron hydroxide from both electrodes is similar in the potential region studied. For the two-mineral electrodes, the increase in arsenopyrite content does not favour the iron hydroxide production.
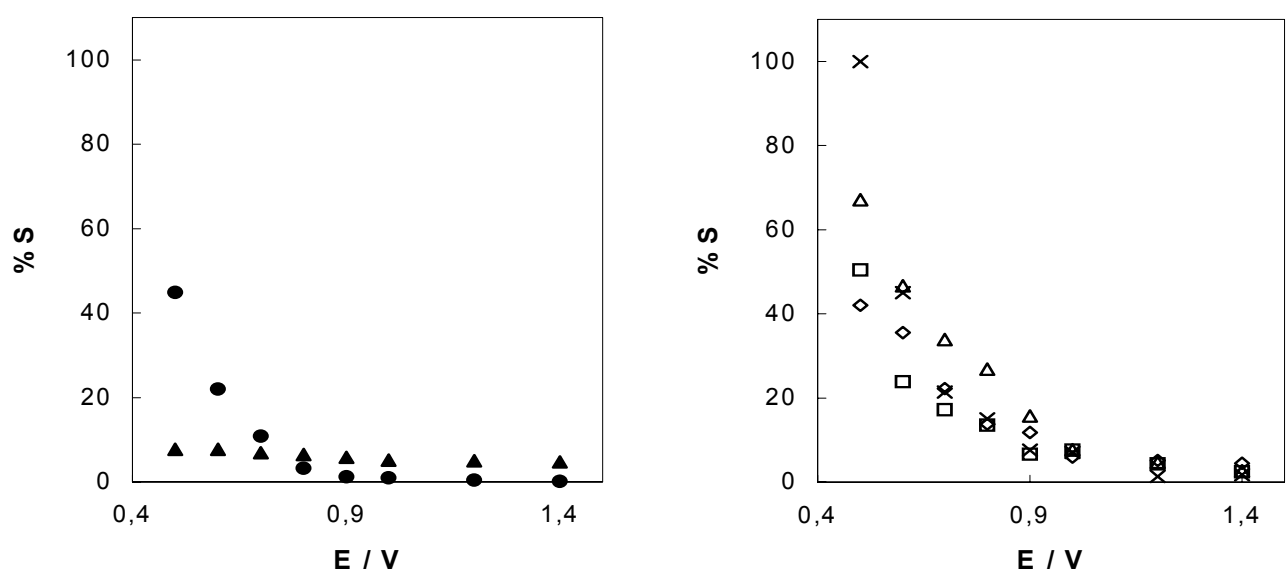

Figure 5. Dependence of $\% \mathrm{~S}$ on the anodic potential limit: $(\boldsymbol{\Delta})$ pyrite alone, $(\boldsymbol{\bullet})$ arsenopyrite alone and pyrite plus: $(\diamond) 20 \%$ arsenopyrite, $(\square)$ ( $40 \%$ arsenopyrite, $(\Delta)$ $60 \%$ arsenopyrite and $(\times) 80 \%$ arsenopyrite. 
Fig. 7 shows the dependence of the $\% \mathrm{SO}_{4}^{2-}, \% \mathrm{~S}$ and $\% \mathrm{Fe}(\mathrm{OH})_{3}$ yield as function of the electrode composition when $\mathrm{E}_{\lambda_{\mathrm{a}}}=0.7 \mathrm{~V}$ (a) and $\mathrm{E}_{\lambda_{\mathrm{a}}}=1.0 \mathrm{~V}$ (b). The value of $\mathrm{E} \lambda \mathrm{a} \leq 0.7 \mathrm{~V}$ was chosen to minimize the formation of arsenic soluble species. The pyrite/arsenopyrite electrodes produce less sulfur than sulfate independently on their composition. However, there is a composition at which the sulfur yield is maximum (60\% arsenopyrite) and, consequently, the sulfate yield minimum.

When $\mathrm{E}_{\lambda \mathrm{a}} \geq 1.0 \mathrm{~V}$ the sulfate production is always greater than that of sulfur for all compositions (Fig. 7b). Thus, at higher overpotentials the electrode dissolution depends mainly on the potential and the electrode composition has none or little influence.

The iron hydroxide yield is practically constant in relation to the composition of the electrodes. For each $\mathrm{E}_{\lambda \mathrm{a}}$, the quantity of orpiment-like compounds was calculated as being $(0.20+0.01) \%$. The charge passed under current peak $\mathrm{C}_{3}$ was calculated to be about $0.83 \mathrm{mC} \mathrm{cm}^{-2}$. Considering the film formed of $\mathrm{As}_{2} \mathrm{~S}_{3}$, with $\rho=3.49 \mathrm{~g} \mathrm{~cm}^{-3}[12]$ and the participation of 2 electrons, the film thickness was evaluated to be about $3 \mathrm{~nm}$, which corresponds to two or three monolayers. The results obtained showed that other factors influence the two-mineral oxidation besides the composition of the electrodes. Two possibilities were examined: the occurrence of galvanic interactions between the minerals in contact and the change in local $\mathrm{pH}$.
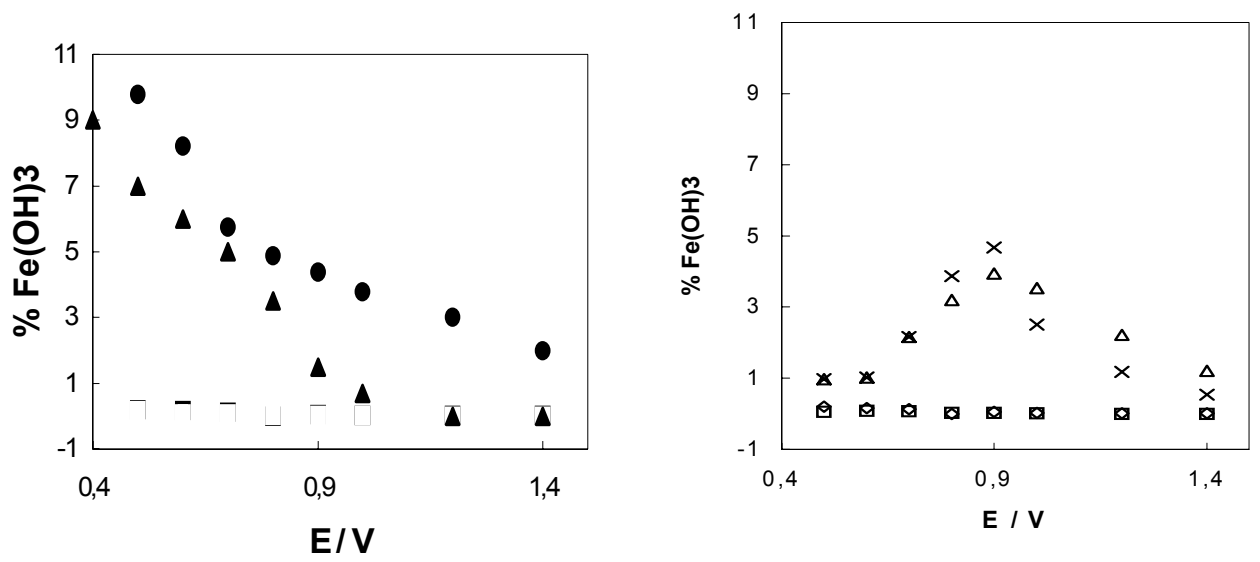

Figure 6. Dependence of $\% \mathrm{Fe}(\mathrm{OH})_{3}$ on the anodic potential limit: $(\boldsymbol{\Delta})$ pyrite alone, $(\bullet)$ arsenopyrite alone and pyrite plus: $(\diamond) 20 \%$ arsenopyrite, $(\square) 40 \%$ arsenopyrite, $(\Delta)$ $60 \%$ arsenopyrite and $(\times) 80 \%$ arsenopyrite. 

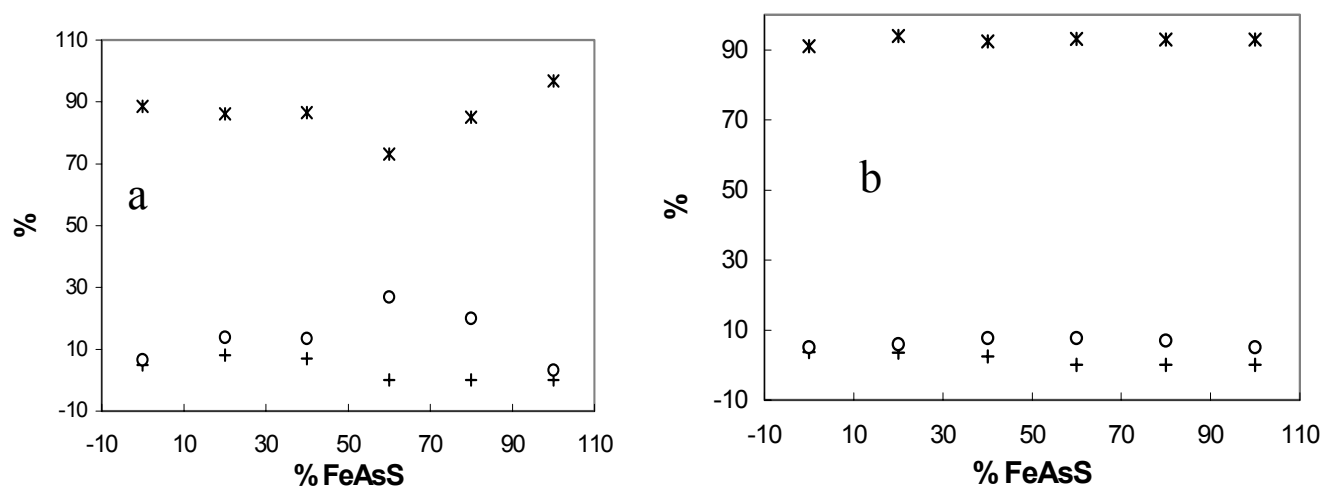

Figure 7. Dependence of the relative quantities of $(*) \mathrm{SO}_{4}{ }^{2-},(\mathrm{o}) \mathrm{S}$ and $(+) \mathrm{Fe}(\mathrm{OH})_{3}$ on the electrode composition; (a) $\mathrm{E}=0.7 \mathrm{~V}$ e (b) $\mathrm{E}=1.0 \mathrm{~V}$.

Galvanic interaction takes place when electrically conducting minerals are in contact, which facilitates charge transfer. The result of galvanic interaction is to change the rates of the anodic and cathodic half-reactions that occur at the surface of each mineral. At open circuit conditions, when pyrite is in contact with arsenopyrite, galvanic cells develop between the minerals. The differences between the rest potentials of minerals represent the driving force for the galvanic process. The mineral with the higher rest potential $\left(\mathrm{FeS}_{2}, \mathrm{E}_{\mathrm{oc}}=0.362 \mathrm{~V}\right)$ acts as the cathode on which the reduction of the ferric ions takes place. The other mineral $\left(\mathrm{FeAsS}, \mathrm{E}_{\mathrm{oc}}=0.300 \mathrm{~V}\right)$ with the lower rest potential anodically dissolves to form elemental sulfur and metal ions [13]. The rate of the reduction of ferric ions is higher on the pyrite surface and increases the rate of dissolution of FeAsS.

In order to verify if these galvanic currents influence the two-mineral oxidation, galvanic couples were constructed as follows:

(A) the anode and the cathode were connected externally and placed next to each other in order to minimise solution voltage losses. The anode was constructed with $3 \mathrm{mg}$ of arsenopyrite and the cathode with $2 \mathrm{mg}$ simulating a single electrode composed by $60 \%$ arsenopyrite and $40 \%$ pyrite; 
(B) a two-mineral electrode was constructed with the anode (60\% arsenopyrite) placed next to the cathode (40\% pyrite) without homogenization of the minerals;

(C) a two-mineral electrode with mixed $60 \%$ arsenopyrite and $40 \%$ pyrite.

The results of experiments $\mathrm{A}, \mathrm{B}$ and $\mathrm{C}$ showed that the electrodes short-circuited externally do not produce sulphur comparable to that obtained when a single electrode containing 60\% arsenopyrite and 40\% pyrite (Tab. 2). Meanwhile the two-mineral electrode presented the expected results. Thus, the increase in sulphur yield is not due to the electrical contact of the pyrite/arsenopyrite. This result certainly evidences that conclusions based on single mineral studies may be quite inaccurate.

Table 2. Dependence of the ratio $\mathrm{Qa} / \mathrm{Qc}$ and of the relative quantities of oxidation products on electrode type.

\begin{tabular}{ccccc}
\hline electrode & $\mathbf{Q a} / \mathbf{Q c}$ & $\mathbf{\%} \mathbf{S}$ & $\mathbf{\%} \mathbf{S O}_{\mathbf{4}}{ }^{2-}$ & $\mathbf{\% ~ F e}(\mathbf{O H})_{\mathbf{3}}$ \\
\hline (A) & 2.3 & 22 & 78 & 5 \\
(B) & 1.10 & 33 & 67 & 5 \\
(C) & 1.00 & 32 & 68 & 6 \\
\hline
\end{tabular}

A change in local $\mathrm{pH}$ should be another factor, which may interfere on the ratio $\mathrm{SO}_{4}{ }^{2-} / \mathrm{S}$. Measurements of the $\mathrm{pH}$ of solutions containing water/pyrite and water/arsenopyrite were carried out in order to verify if a local change of $\mathrm{pH}$ could influence the sulfur yield of the two-mineral electrodes. The results are shown in Table 3.

When the pyrite content is greater than $40 \%$ there is no change in the $\mathrm{pH}$ value in relation to that measured in a solution containing pyrite alone. The dissolution of pyrite results in the production of $\mathrm{H}^{+}$ions, which can lower the local $\mathrm{pH}$ at the electrode surface. The thiosulfate decomposition depends considerably on $\mathrm{pH}$, being the kinetics of sulfur formation a first order reaction in relation to the $\mathrm{H}^{+}$ concentration. When the arsenopyrite content is higher than $40 \%$, a slight increase in $\mathrm{pH}$ is noticed. 
Comparing the results obtained from $\mathrm{pH}$ measurements with those shown in Fig. 7 , it can be inferred that when the electrodes contain more than $40 \%$ pyrite the local $\mathrm{pH}$ decreases slightly and the decomposition of thiosulfate is enhanced. Thus, sulphur production is favoured. When the arsenopyrite content is greater than $60 \%$, there is an increase in the local $\mathrm{pH}$ disfavouring the thiosulfate decomposition. It is worth noting that the increase in arsenopyrite content does not change significantly the oxidation mechanism.

Table 3. $\mathrm{pH}$ values of aqueous solutions containing $5 \mathrm{~g}$ of mineral(s) in $25 \mathrm{~mL}$ water.

\begin{tabular}{cc}
\hline mineral & pH \\
\hline pyrite & 4.0 \\
$20 \%$ arsenopyrite / $80 \%$ pyrite & 4.0 \\
$40 \%$ arsenopyrite / $60 \%$ pyrite & 4.0 \\
$60 \%$ arsenopyrite / $40 \%$ pyrite & 4.1 \\
$80 \%$ arsenopyrite / $20 \%$ pyrite & 4.2 \\
arsenopyrite & 4.2 \\
\hline
\end{tabular}

\section{Conclusions}

The influence of arsenopyrite content in a pyrite/arsenopyrite electrode was examined:

(1) At potential next to the open circuit potential, the reactions producing sulfur are slightly favoured.

(2) The presence of arsenopyrite enhances sulfate and soluble compounds formation. Pyrite/arsenopyrite combination favours soluble compounds production $\left(\mathrm{SO}_{4}{ }^{2-} / \mathrm{H}_{2} \mathrm{AsO}_{4}^{-}\right)$.

(3) At potentials more positive than $0.85 \mathrm{~V}$ the release of arsenic compounds to the environment is favoured.

(4) At higher overpotentials the electrode dissolution depends mainly on the potential and the electrode composition has none or little influence.

(5) Galvanic interactions may occur, but the decrease in sulfur yield, when pyrite $>40 \%$, is not due to the electrical contact between pyrite and arsenopyrite. 
(6) The presence of more than $40 \%$ pyrite in the mixture enhances the $\mathrm{H}^{+}$ production, which lowers the local $\mathrm{pH}$ and favours thiosulfate decomposition. Thus, in this condition a little more sulfate is produced.

(7) Remediation strategies for disturbed lands containing sulfide minerals must consider the quantity and the nature of sulfide minerals present.

\section{Acknowledgements}

Financial support from Fundação de Amparo à Pesquisa do Estado de São Paulo, FAPESP, is gratefully recognized.

\section{References}

1. I.C. Hamilton, R. Woods, J. Electroanal. Chem. 118 (1981) 327.

2. B.F. Giannetti, S.H. Bonilla, C.F. Zinola, T. Rabóczkay, Hydrometallurgy $60(2001) 41$.

3. H.K. Lin, Z.M. Zheng, Hydrometallurgy 42 (1996) 411.

4. M.J.V. Beattie, G.W. Poling, Int. J. Miner. Process. 20 (1987) 87.

5. V. Sanchez, J.B. Hiskey, Met. Trans. B. 19 (1988) 943.

6. P.G. Fernandez, H.G. Linge, M.W. Wadsley, J. Appl. Electrochem. 26 (1996) 575.

7. P.G. Fernandez, H.G. Linge, M.W. Wadsley, J. Appl. Electrochem. 26 (1996) 585 .

8. M.J.A. Vreugde, Ph.D. Thesis, University of British Columbia, Canada, 1982.

9. B.W. Vink, Chemical Geology 130 (1996) 21.

10. A. Vogel, "Química Analílica Qualitativa”, Ed. Kapeluz, Buenos Aires, 1983.

11. K.K. Mishra, K. Osseo-Asare, J. Electrochem. Soc. 135 (1988) 2502.

12. J.D. Dana, "Manual de Mineralogia", Livros Técnicos e Científicos Editora, São Paulo, 1970.

13. P.R. Holmes, F.K. Crundwell, Hydrometallurgy 39 (1995) 353. 